\title{
Examining the Learners' Attitudes towards Learning English Language at Imam Abdulrahman Bin Faisal University
}

\author{
Dr. Ayman Hamid AL-Takhayinh* \\ Department of English, Imam Abdulrahman Bin Faisal University, Dammam, Saudi Arabia \\ E-mail: ahaltakhayih@iau.edu.sa \\ Sufyan Irshaed Abdelrahim Magableh \\ Department of English, Imam Abdulrahman Bin Faisal University, Dammam, Saudi Arabia \\ E-mail: simagableh@iau.edu.sa \\ Jassar Mohammad Mustafa Alahmad \\ Department of English, Imam Abdulrahman Bin Faisal University, Dammam, Saudi Arabia \\ E-mail: jmalahmad@iau.edu.sa
}

\begin{abstract}
English language proficiency has become one of the crucial parts in an EFL context. The achievement of language proficiency not only requires a well-structured curriculum and competent teachers but also the students' attitudes towards the language learning. Hence, this study examines the EFL learners' attitudes towards learning English as a foreign language at Imam Abdulrahman Bin Faisal University. The sample of the study were 120 EFL students at the Deanship of the Preparatory Year and Supporting Studies, all native speakers of Arabic at Imam Abdulrahman Bin Faisal University. The data of the study were analyzed by using descriptive statistics in SPSS version 22.0, for analysis. The statistical analysis discloses that (1) the students have positive attitudes towards leaning English language. (2) There is no significant difference between the students at the four levels in their attitudes towards learning English language. (3) The analysis showed that the students have integrativeinstrumental attitudes to learn English language which is an advantage. (4) It is also found that the students do not have negative attitudes or fear towards learning English. Further, it is also noticed that the students are frequently involved in watching English programs and movies. Finally, it is hoped that the findings of this study will help in further improvements of the students' ability in learning English as a foreign language. The positive students' attitude should be taken into consideration. Also, Saudi EFL teachers should take the positive of students' attitude towards learning English into consideration as well.
\end{abstract}

Keywords: Attitude, Saudi EFL learners, English as a foreign language, Imam Abdulrahman Bin Faisal University DOI: $10.7176 / \mathrm{JEP} / 13-5-05$

Publication date: February $28^{\text {th }} 2022$

\section{Introduction}

In Saudi universities, English is taught as a foreign language. Syllabus makers and EFL teachers have realized that there is great need to understand the term attitudes for Saudi EFL learners in learning English as foreign language at Saudi universities. Moreover, there are many researchers and scholars who dealt with the term attitude. Allport (1935) defined attitudes as the most distinctive and important term in social psychology. Also, Morgan (1993) stated that attitudes has a role not only in psychology but also in language learning. Attitudes donates to the progress of language learning and language comprehension for learners learning language as a foreign or second language. Based on the researches on attitudes, various fields have dealt with the term attitudes like social psychology, language learning, socio-linguistics and neuro-linguistics. The term attitude has been defined by many definitions from the point views of human's life aspects. According to definition of Allport (1935) he defines attitude as "a mental and neutral state of readiness, systematized via practice, exerting a dynamic and directive influence upon human's reaction to all situations and objectives with which it is connected" (p. 810). Other definition by

Gardner in (1985) gives a definition to attitude as he stressed the connection concerning attitude, opinion and belief. To Gardner attitude is "an assessment reaction to some referent or attitude object, inferred on the base of the human's belief or opinion about the referent" (p. 9). Once more, attitude initially taken to indicate the body's disposition, but currently it is primarily used for human's behavior, thoughts, desires and feelings "settled behavior or manner of acting as representative of feeling; attitude of mind; deliberately adopted, or, habitual, made of regarding the object of thought" (Margon, 1993, p. 64). This definition of Morgan dose not only consider attitude as feelings matter but as well a matter of thoughts and behavior. The types of attitude that are cognitive and conative are repeatedly involved in most the texts of social psychology. 


\subsection{Components of Attitudes}

Attitude has got three components, (i) affective, (ii) cognition, (iii) behavior (Gardner, 1985a; Malim and Birch, 1998; Fasio, 1986; Backer, 1992). The affective component which is the first component of attitude contains emotions towards the assessment of purpose of attitude. Secondly, attitude of cognitive which donates to the knowledge or a human's belief about the purpose of attitude. The last type of attitude, is about a component of human's behavior that got relation with actions or intentions linked to the purpose attitude.

These three component of attitude are broadly recognized by many scholars, as stated by Birch and Malim, but lately uncertainty was come up upon the component of behavior. Numerous researchers state that the difficulty lies in viewing the human's attitude to get something that may seem realistic to help us to guess the human's behavior. Backer (1992) has the same opinion that humans do not continuously behave in ways which are constant with their attitudes (p.11).

Ellis (1994, p.199) discusses the main features of attitude as follows:

1. "Attitudes are cognitive (i.e. are capable of being thought about) and affective (i.e. have feeling and emotions attached to them").

2. "Attitudes are dimensional rather than bipolar-they vary in degree of favorability and unfavorably".

3. "Attitudes predispose a person to act in a certain way, but the relationship attitudes and actions is not a strong one".

4. "Attitudes are learnt, not inherited or genetically endowed".

5. "Attitudes tend to persist but they can be modified by experiences".

1.1.1 Objectives

The study aims to examine the following objectives:

1. To examine whether the students have positive attitudes towards learning English as a foreign language at the Deanship of the Preparatory Year and Supporting Studies at Imam Abdulrahman Bin Faisal University.

2. To examine whether there is significant difference between the students at the four levels in their attitudes towards learning English language.

3. To see whether the students have integrative-instrumental attitudes to learn English language.

\section{Methodology}

The purpose of this study is to examining the EFL learners' attitudes towards learning English as a foreign language at the Deanship of the Preparatory Year and Supporting Studies at Imam Abdulrahman Bin Faisal University. Also, to have an insight into the minds of the learners and to view their preferences and attitude towards the English language is considered. In the following sections, the methods for the current study are presented.

\subsection{Participant' Sitting}

Participants of this study are 120 undergraduate EFL students at the Deanship of the Preparatory Year and Supporting Studies at Imam Abdulrahman Bin Faisal University, all native speakers of Arabic. The participants are in the range age from 18 to 26 years. The researchers had a sample of 120 students from the three levels at the Deanship of the Preparatory Year and Supporting Studies at Imam Abdulrahman Bin Faisal University. The deanship of preparatory year and supporting studies is found at imam Abdulrahman Bin Faisal University to prepare students for university life and develop their skills in English language. Moreover, English language department has been found in the deanship of preparatory year and supporting studies to meet the needs of the students and raise their level in general and academic English. In addition, English language department enables the students to have a transition from high school to university in many different fields including English language, communication skills and scientific knowledge needed for their future majors at the university and their career alike, by focusing on teaching the four skills (Reading, Writing, Listening, Speaking), and English for Academic and Specific purposes. Hence, the study considers three levels of the Preparatory Year and Supporting Studies, i.e., beginner level, intermediate level and advanced level as shown in Table (1).

Table (1): Participants Distribution

\begin{tabular}{|c|c|c|c|}
\hline Beginner level & Intermediate level & Advanced level & Total \\
\hline 40 & 40 & 40 & 120 \\
\hline
\end{tabular}

\subsection{Data collection}

Data of the current study were collected through questionnaire which consists of two parts (A and B). Questionnaire (A) consists of six statements with a five-point scale and part (B) questionnaire consists of five statement about the students negative attitudes. Statements in the questionnaire were related to learners' attitudes towards learning English as a foreign language at Imam Abdulrahman Bin Faisal University.

The respondents were requested to read the statements given carefully and choose only one response which 
they thought most appropriate from the five responses (options) provided which were:

- $\quad$ Strongly Agree

- $\quad$ Agree

- Neutral

- Disagree

- $\quad$ Strongly Disagree

\subsection{Quantitative Analysis}

For achieving the research questions of this study, the researchers deal with the statistical analysis of attitudes towards learning English as a foreign language at Imam Abdulrahman Bin Faisal University. Data were first sorted out, i.e. edited, coded, categorized and then tabularized. All data that were sorted out and categorized were organized in detached sheets. After the procedures of coding, categorization and tabularization, the data were inserted to SPSS (Statistical Package for the Social Sciences) version 22.0, for analysis.

\subsection{Results and Discussion}

1. I like English culture and I want to interact with speakers of English.

Table (2): shows the descriptive statistics of the learners' responses on item (1)

\begin{tabular}{|l|c|c|c|}
\hline Level & $\mathbf{N}$ & Mean & Std. Deviation \\
\hline Beginner & 40 & 3.87 & 1.04 \\
\hline Intermediate & 39 & 4.21 & .68 \\
\hline Advanced & 39 & 4.07 & .94 \\
\hline Total & 118 & 3.98 & .91 \\
\hline
\end{tabular}

Table (3): shows the distribution of the learners' responses on item (1)

\begin{tabular}{|c|c|c|c|c|c|c|c|c|}
\hline & & & $\begin{array}{l}\text { Strongly } \\
\text { Disagree }\end{array}$ & Disagree & Neutral & Agree & $\begin{array}{c}\text { Strongly } \\
\text { Agree }\end{array}$ & Total \\
\hline \multirow[t]{6}{*}{ Level } & \multirow[t]{2}{*}{ Beginner } & $\begin{array}{l}\text { Count with } \\
\text { Level }\end{array}$ & 1 & 1 & 9 & 9 & 10 & 30 \\
\hline & & $\begin{array}{c}\text { Percentage } \\
\text { within Level }\end{array}$ & $3.3 \%$ & $3.3 \%$ & $30 \%$ & $30 \%$ & $33.3 \%$ & $100 \%$ \\
\hline & \multirow[t]{2}{*}{ Intermediate } & $\begin{array}{l}\text { Count with } \\
\text { Level }\end{array}$ & 0 & 0 & 4 & 15 & 10 & 29 \\
\hline & & $\begin{array}{c}\text { Percentage } \\
\text { within Level }\end{array}$ & $.0 \%$ & $.0 \%$ & $13.8 \%$ & $51.7 \%$ & $34.5 \%$ & $100 \%$ \\
\hline & \multirow[t]{2}{*}{ Advanced } & $\begin{array}{c}\text { Count with } \\
\text { Level }\end{array}$ & 0 & 2 & 6 & 10 & 12 & 30 \\
\hline & & $\begin{array}{c}\text { Percentage } \\
\text { within Level }\end{array}$ & $.0 \%$ & $6.7 \%$ & $20 \%$ & $33.3 \%$ & $40 \%$ & $100 \%$ \\
\hline \multirow{2}{*}{\multicolumn{2}{|c|}{ Total }} & $\begin{array}{c}\text { Count with } \\
\text { Level }\end{array}$ & 1 & 6 & 25 & 48 & 38 & 118 \\
\hline & & $\begin{array}{c}\text { Percentage } \\
\text { within Level }\end{array}$ & $.8 \%$ & $5.1 \%$ & $21.2 \%$ & $40.7 \%$ & $32.2 \%$ & $100 \%$ \\
\hline
\end{tabular}

It is shown in Tables (2 and 3 ) that the mean score of the 118 students' responses is (3.98) and the standard deviation is (.91), showing that the responses of the 118 students are clustered around 'agree' and 'strongly agree' options. Moreover, 86 respondents $(72.9 \%)$ showed that they are integratively having attitudes towards learn English as they reported that they like English culture and they want to interact with speakers of English, while seven respondents (5.9\%) showed that they are not integratively having attitudes towards learn English as they reported that they do not like English culture and they do not want to interact with speakers of English. The level of agreement shows that most of the students are integratively having attitudes towards learn English at Imam Abdulrahman Bin Faisal University.

2. English Language is easy to learn.

Table (4): shows the descriptive statistics of the learners' responses on item (2)

\begin{tabular}{|l|c|c|c|}
\hline Level & N & Mean & Std. Deviation \\
\hline Beginner & 40 & 3.57 & .97 \\
\hline Intermediate & 39 & 3.90 & .98 \\
\hline Advanced & 40 & 3.90 & .96 \\
\hline Total & 119 & 3.81 & .95 \\
\hline
\end{tabular}


Table (5): shows the distribution of the learners' responses on item (2)

\begin{tabular}{|l|l|c|c|c|c|c|c|c|}
\hline \multicolumn{2}{|c|}{} & $\begin{array}{c}\text { Strongly } \\
\text { Disagree }\end{array}$ & Disagree & Neutral & Agree & $\begin{array}{c}\text { Strongly } \\
\text { Agree }\end{array}$ & Total \\
\hline \multirow{3}{*}{ Level } & Beginner & $\begin{array}{c}\text { Count with } \\
\text { Level }\end{array}$ & 1 & 4 & 5 & 17 & 3 & 30 \\
\cline { 3 - 9 } & $\begin{array}{c}\text { Percentage } \\
\text { within Level }\end{array}$ & $3.3 \%$ & $13.3 \%$ & $16.7 \%$ & $56.7 \%$ & $10 \%$ & $100 \%$ \\
\cline { 2 - 9 } & Intermediate & $\begin{array}{c}\text { Count with } \\
\text { Level }\end{array}$ & 1 & 2 & 3 & 16 & 7 & 29 \\
\cline { 2 - 9 } & $\begin{array}{c}\text { Percentage } \\
\text { within Level }\end{array}$ & $3.4 \%$ & $6.9 \%$ & $10.3 \%$ & $55.2 \%$ & $24.1 \%$ & $100 \%$ \\
\cline { 2 - 9 } & Advanced & $\begin{array}{c}\text { Count with } \\
\text { Level }\end{array}$ & 0 & 3 & 6 & 12 & 9 & 30 \\
\cline { 2 - 9 } & $\begin{array}{c}\text { Percentage } \\
\text { within Level }\end{array}$ & $.0 \%$ & $10 \%$ & $20 \%$ & $40 \%$ & $30 \%$ & $100 \%$ \\
\hline Total & $\begin{array}{c}\text { Count with } \\
\text { Level }\end{array}$ & 2 & 13 & 16 & 63 & 25 & 119 \\
\cline { 2 - 9 } & $\begin{array}{c}\text { Percentage } \\
\text { within Level }\end{array}$ & $1.7 \%$ & $10.9 \%$ & $13.4 \%$ & $52.9 \%$ & $21 \%$ & $100 \%$ \\
\hline
\end{tabular}

The Tables (4 and 5) shows mean score of the responses of the 119 students surveyed is (3.81) and the standard deviation is (.95), showing that the responses are clustered around 'agree' option. To be specific, 25 respondents $(21.3 \%)$ strongly agreed with the statement, 63 respondents $(52.9 \%)$ agreed with the statement, 13 respondents $(10.9 \%)$ disagreed with the statement, two respondents $(1.7 \%)$ strongly disagreed with the statement, 16 respondents (13.4) remained neutral on the issue whether or not English language is easy to learn and one respondent missed the statement. This level of agreement (73.9\%) shows that most of the students have a positive attitude towards learning English at Imam Abdulrahman Bin Faisal University.

3. I learn English because I am required to learn it.

Table (6): shows the descriptive statistics of the learners' responses on item (3)

\begin{tabular}{|l|c|c|c|}
\hline \multicolumn{1}{|c|}{ Level } & $\mathbf{N}$ & Mean & Std. Deviation \\
\hline Beginner & 40 & 4.70 & .79 \\
\hline Intermediate & 40 & 4.70 & .47 \\
\hline Advanced & 40 & 4.67 & .66 \\
\hline Total & 120 & 4.70 & .60 \\
\hline
\end{tabular}

Table (7): shows the distribution of the learners' responses on item (3)

\begin{tabular}{|l|l|c|c|c|c|c|c|c|}
\hline \multicolumn{2}{|c|}{} & $\begin{array}{c}\text { Strongly } \\
\text { Disagre }\end{array}$ & Disagree & Neutral & Agree & $\begin{array}{c}\text { Strongly } \\
\text { Agree }\end{array}$ & Total \\
\hline \multirow{3}{*}{ Level } & Beginner & $\begin{array}{c}\text { Count with } \\
\text { Level }\end{array}$ & 1 & 7 & 0 & 5 & 24 & 30 \\
\cline { 3 - 9 } & $\begin{array}{c}\text { Percentage } \\
\text { within Level }\end{array}$ & $3.3 \%$ & $23.3 \%$ & $.0 \%$ & $16.7 \%$ & $80.0 \%$ & $100.0 \%$ \\
\cline { 2 - 9 } & Intermediate & $\begin{array}{c}\text { Count with } \\
\text { Level }\end{array}$ & 0 & 6 & 0 & 9 & 21 & 30 \\
\cline { 2 - 9 } & $\begin{array}{c}\text { Percentage } \\
\text { within Level }\end{array}$ & $.0 \%$ & $20.0 \%$ & $.0 \%$ & $30.0 \%$ & $70.0 \%$ & $100.0 \%$ \\
\cline { 2 - 9 } & Advanced & $\begin{array}{c}\text { Count with } \\
\text { Level }\end{array}$ & 0 & 7 & 3 & 4 & 23 & 30 \\
\cline { 2 - 9 } & $\begin{array}{c}\text { Percentage } \\
\text { within Level }\end{array}$ & $.0 \%$ & $23.3 \%$ & $10.0 \%$ & $13.3 \%$ & $76.7 \%$ & $100.0 \%$ \\
\hline $\begin{array}{c}\text { Count with } \\
\text { Level }\end{array}$ & $\begin{array}{c}\text { Percentage } \\
\text { within Level }\end{array}$ & $.8 \%$ & $21.7 \%$ & $21.7 \%$ & $21.7 \%$ & $75.0 \%$ & $100.0 \%$ \\
\hline
\end{tabular}

Tables (6 and 7) shows the mean score of the four years students' responses is (4.70) and the standard deviation is (.60), showing that the responses of all the respondents are clustered around 'strongly agree' option. To be specific, 116 respondents who represent (96.7\%) said that they learn English because they are required to learn it, only one respondent who represents . $8 \%$ said that he/she does not like English and English speakers and three respondents who represent $2.5 \%$ remained neutral on the issue of whether or not they learn English because 
they are required to learn it. The high level of agreement shows the students' positive attitudes towards learning English as it is required for them at Imam Abdulrahman Bin Faisal University.

4. I learn English because I want to get a good job.

Table (7): shows the descriptive statistics of the learners' responses on item (4)

\begin{tabular}{|l|c|c|c|}
\hline Level & $\mathbf{N}$ & Mean & Std. Deviation \\
\hline Beginner & 40 & 3.27 & 1.08 \\
\hline Intermediate & 39 & 3.38 & 1.45 \\
\hline Advanced & 40 & 3.53 & 1.22 \\
\hline Total & 119 & 3.38 & 1.30 \\
\hline
\end{tabular}

Table (8): shows the distribution of the learners' responses on item (4)

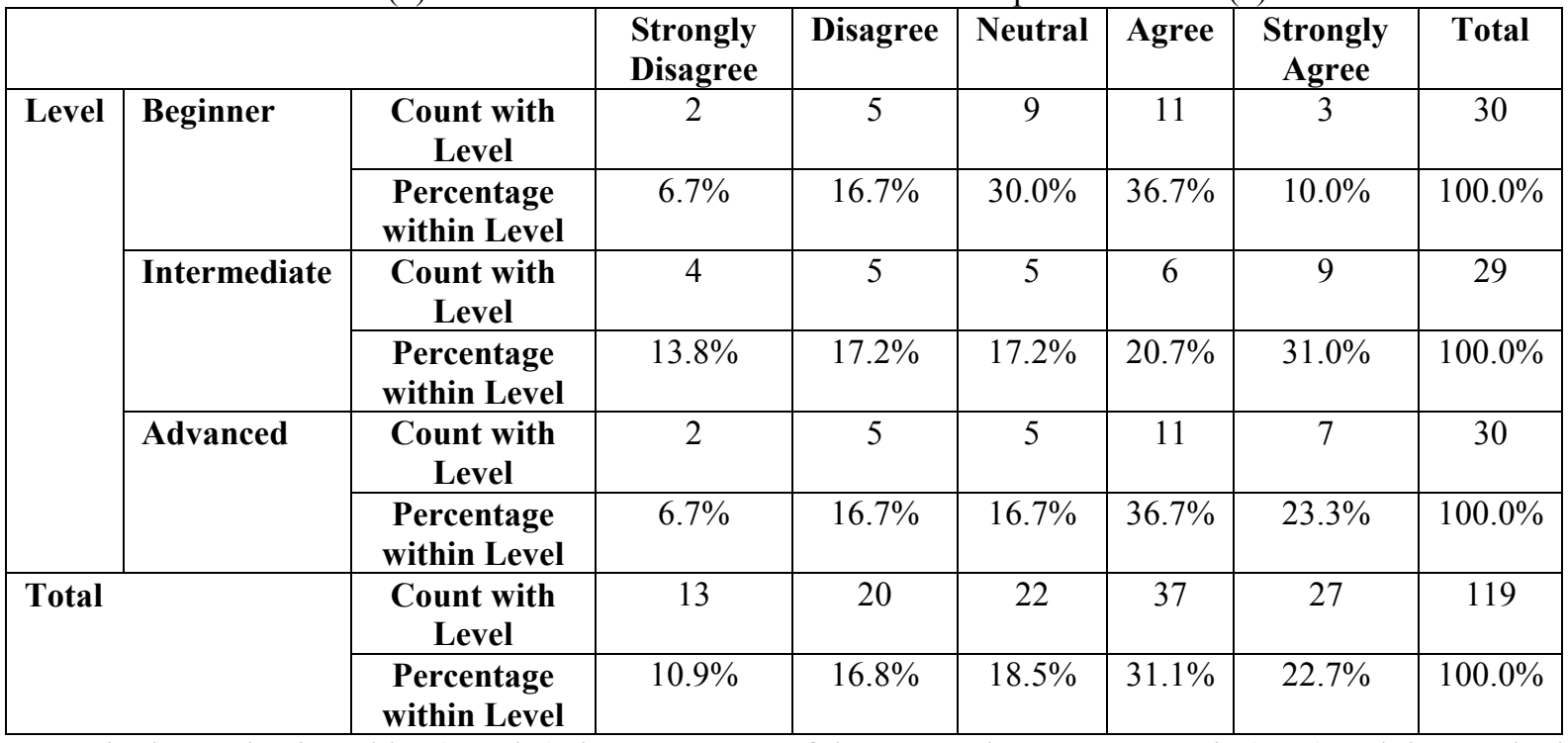

It is shown that in Tables (7 and 8) the mean score of the 119 students' responses is (3.38) and the standard deviation is (1.30). It is showing that the responses are clustered around 'agree' and 'strongly agree' options. To clarify it, 64 respondents (53.8\%) showed that they are instrumentally motivated to learn English in order to get a good job as they reported, while 33 respondents $(27.7 \%)$ showed that they are not instrumentally motivated to learn English as they reported that they learn English for the purpose of getting a good jobs. The level of agreement shows that more students are instrumentally having attitudes towards learning English in order to get a good job as compared to those who did not show that they are not instrumentally having attitudes towards learning English at Imam Abdulrahman Bin Faisal University.

5. I like watching English programs and movies.

Table (9): shows the descriptive statistics of the learners' responses on item (5)

\begin{tabular}{|l|c|c|c|}
\hline Level & N & Mean & Std. Deviation \\
\hline Beginner & 40 & 3.87 & .90 \\
\hline Intermediate & 38 & 3.61 & .88 \\
\hline Advanced & 40 & 3.77 & .82 \\
\hline Total & 117 & 3.80 & .83 \\
\hline
\end{tabular}


Table (10): shows the distribution of the learners' responses on item (5)

\begin{tabular}{|c|c|c|c|c|c|c|c|c|}
\hline & $\begin{array}{l}\text { Strongly } \\
\text { Disagree }\end{array}$ & Disagree & Neutral & Agree & $\begin{array}{l}\text { Strongly } \\
\text { Agree }\end{array}$ & Total \\
\hline \multirow[t]{6}{*}{ Level } & \multirow[t]{2}{*}{ Beginner } & $\begin{array}{l}\text { Count with } \\
\text { Level }\end{array}$ & 0 & 2 & 8 & 12 & 8 & 30 \\
\hline & & $\begin{array}{l}\text { \% age within } \\
\text { Level }\end{array}$ & $.0 \%$ & $6.7 \%$ & $26.7 \%$ & $40.0 \%$ & $26.7 \%$ & $100.0 \%$ \\
\hline & \multirow[t]{2}{*}{ Intermediate } & $\begin{array}{l}\text { Count with } \\
\text { Level }\end{array}$ & 0 & 3 & 9 & 12 & 4 & 28 \\
\hline & & $\begin{array}{l}\text { Percentage } \\
\text { within Level }\end{array}$ & $.0 \%$ & $10.7 \%$ & $32.1 \%$ & $42.9 \%$ & $14.3 \%$ & $100.0 \%$ \\
\hline & \multirow[t]{2}{*}{ Advanced } & $\begin{array}{l}\text { Count with } \\
\text { Level }\end{array}$ & 1 & 1 & 5 & 20 & 3 & 30 \\
\hline & & $\begin{array}{l}\text { Percentage } \\
\text { within Level }\end{array}$ & $3.3 \%$ & $3.3 \%$ & $16.7 \%$ & $66.7 \%$ & $10.0 \%$ & $100.0 \%$ \\
\hline \multirow{2}{*}{\multicolumn{2}{|c|}{ Total }} & $\begin{array}{l}\text { Count with } \\
\text { Level }\end{array}$ & 1 & 7 & 27 & 61 & 21 & 117 \\
\hline & & $\begin{array}{l}\text { Percentage } \\
\text { within Level }\end{array}$ & $.9 \%$ & $6.0 \%$ & $23.1 \%$ & $52.1 \%$ & $17.9 \%$ & $100.0 \%$ \\
\hline
\end{tabular}

Tables of (9 and 10) give the mean score of the 117 students' responses is (3.80) and the standard deviation is (.83), showing that the responses are clustered around 'agree' and 'neutral' option. To clarify it, 82 respondents $(70 \%)$ showed a positive attitude towards watching movies in English as they said that watching movies in English for them is a great benefit, while only eight respondents $(6.9 \%)$ showed a negative attitude towards watching movies in English as they said watching movies in English for them is not an easy task. There were 27 respondents (23.1\%) remained neutral on the statement and three respondents left the statement blank. This level of agreement showed that most of the students surveyed have a positive attitude towards watching movies in English at Imam Abdulrahman Bin Faisal University.

6. I think of continuing my studies in English.

Table (11): shows the descriptive statistics of the learners' responses on item (6)

\begin{tabular}{|l|c|c|c|}
\hline Level & $\mathbf{N}$ & Mean & Std. Deviation \\
\hline Beginner & 39 & 4.17 & .79 \\
\hline Intermediate & 40 & 4.52 & .63 \\
\hline Advanced & 40 & 4.03 & 1.15 \\
\hline Total & 118 & 4.15 & .95 \\
\hline
\end{tabular}

Table (12): shows the distribution of the learners' responses on item (6)

\begin{tabular}{|c|l|c|c|c|c|c|c|c|}
\hline \multicolumn{2}{|c|}{} & $\begin{array}{c}\text { Strongly } \\
\text { Disagree }\end{array}$ & Disagree & Neutral & Agree & $\begin{array}{c}\text { Strongly } \\
\text { Agree }\end{array}$ & Total \\
\hline \multirow{3}{*}{ Level } & Beginner & $\begin{array}{c}\text { Count with } \\
\text { Level }\end{array}$ & 0 & 1 & 4 & 14 & 11 & 30 \\
\cline { 3 - 9 } & $\begin{array}{c}\text { Percentage } \\
\text { within Level }\end{array}$ & $.0 \%$ & $3.3 \%$ & $13.3 \%$ & $46.7 \%$ & $36.7 \%$ & $100.0 \%$ \\
\cline { 2 - 9 } Intermediate & $\begin{array}{c}\text { Count with } \\
\text { Level }\end{array}$ & 0 & 0 & 2 & 10 & 17 & 29 \\
\cline { 2 - 9 } & $\begin{array}{c}\text { Percentage } \\
\text { within Level }\end{array}$ & $.0 \%$ & $.0 \%$ & $6.9 \%$ & $34.5 \%$ & $58.6 \%$ & $100.0 \%$ \\
\cline { 2 - 9 } Total & $\begin{array}{c}\text { Count with } \\
\text { Level }\end{array}$ & 1 & 2 & 6 & 6 & 14 & 29 \\
\cline { 2 - 9 } & $\begin{array}{c}\text { Percentage } \\
\text { within Level }\end{array}$ & $3.4 \%$ & $6.9 \%$ & $20.7 \%$ & $20.7 \%$ & $48.3 \%$ & $100.0 \%$ \\
\hline $\begin{array}{c}\text { Count with } \\
\text { Level }\end{array}$ & 2 & 5 & 18 & 41 & 52 & 118 \\
\cline { 2 - 9 } & $\begin{array}{c}\text { Percentage } \\
\text { within Level }\end{array}$ & $1.7 \%$ & $4.2 \%$ & $15.3 \%$ & $34.7 \%$ & $44.1 \%$ & $100.0 \%$ \\
\hline
\end{tabular}

As shown in above Tables (11 and 12) that the mean score of the 118 students' responses is (4.15) and the standard deviation is (.95), showing that the responses are clustered around 'agree' and 'strongly agree' options. To clarify it, 93 respondents (78.8\%) showed that they have an interest I think of continuing their studies in English as they reported that they think of continuing their studies in English, while only seven respondents (5.9\%) showed 
that they do not think of continuing their studies in English and 18 respondents $(15.3 \%)$ remained neutral and two respondents left the statement blank. The high level of agreement shows that most of the students have an interest to continue their studies in English and the low level of disagreement shows that there are some of the students who do not think of continuing their studies in English.

Here, it can be inferred that most of the students surveyed showed positive attitudes towards English at Imam Abdulrahman Bin Faisal University. Taking into consideration the fact that "both integrative and instrumental attitudes may lead to success, but lack of either causes problems" (Cook, 1991, p. 75), the students surveyed showed that they have integrative-instrumental attitudes towards to learn English.

Lastly, the overall students at the four levels also were given some statements in order to see whether they are having negative attitudes towards learning English language or no. The results revealed by the analysis of these negative statements are presented in Table (13).

\begin{tabular}{|c|c|c|c|c|c|c|}
\hline $\mathrm{N}$ & \multirow[t]{2}{*}{ Statements } & $\begin{array}{l}\text { Strongly } \\
\text { agree }\end{array}$ & Agree & Natural & Disagree & $\begin{array}{l}\text { Strongly } \\
\text { disagree }\end{array}$ \\
\hline & & $\%$ & $\%$ & $\%$ & $\%$ & $\%$ \\
\hline 1 & Studying English causes fear for me. & 7 & 13 & 17 & 55 & 61 \\
\hline 2 & $\begin{array}{l}\text { I believe that English is difficult and } \\
\text { complicated to learn. }\end{array}$ & 13 & 13 & 20 & 44 & 57 \\
\hline 3 & $\begin{array}{l}\text { Learning English is not a primary goal } \\
\text { for me. }\end{array}$ & 11 & 20 & 30 & 47 & 68 \\
\hline 4 & $\begin{array}{l}\text { It is not easy to understand what } \\
\text { others say in English. }\end{array}$ & 15 & 13 & 20 & 50 & 67 \\
\hline 5 & I don't prefer to speak in English. & 0 & 13 & 23 & 54 & 68 \\
\hline
\end{tabular}

Examining the responses of students to the lowest levels of the negative attitudes, Table (13) shows that (66\%) of students, $(55 \%)$ disagree and (61\%) strongly disagree on the fact that studying English causes fear for them, in comparison with $(20 \%)$ of them who always have fear. Meanwhile, $60 \%$ of participant students (44\%) disagree and $(57 \%)$ strongly disagree that they believe that English is difficult and complicated to learn. On the opposite, $(64 \%)$ of respondents, $(47 \%)$ disagree and another $(68 \%)$ strongly disagree on that learning English is not a primary goal for them. In other words, the majority of them stated that they agree that it is a primary goal for them. Other statement that it is not easy to understand what others say in English with (50\%) disagree and (67\%) disagree. In last statement that I don't prefer to speak in English, where the majority disagree with (54\%) and strongly disagree with $(68 \%)$.

\section{Conclusion}

The study resulted many useful and encouraging findings. It is heartening to notice that Saudi EFL students at Imam Abdulrahman Bin Faisal University have started taking more interest in using English language. The statistical analysis shows that the Saudi EFL students showed a positive attitude towards English and English language at Imam Abdulrahman Bin Faisal University. Further, the students' responses showed that they have integrative-instrumental attitudes to learn English language. It was also noticed that the students involve always in watching English programs and movies. Moreover, it is also found that the students do not have negative attitudes or fear towards learning English. Finally, it is hoped that the findings of this study may help in further improvement of the students' ability in learning English. The positive attitudes of the students should be taking in consideration for more improvement of students' ability. Also, teachers can take notice of the result that students are positively involve in watching English programs and movies and, their activities in English language learning.

\section{References}

Allport, G. W. (1971). Attitudes. In K. Thomas (Ed.), Attitudes and behavior. Harmondsworth, UK: Penguin.

Baker, C. (1992). Attitudes and language. Clevedon, UK: Multilingual Matters.

Brown, H. D. (2000). Principles of language learning and teaching. (4th ed.). New York: Longman.

Ellis, R. (1994). The study of second language acquisition. Oxford: Oxford University Press.

Fasio, R. (1986). How do attitudes guide behaviour? In Ran and Jilles (eds.).

Gardner, R. C. (1985b). The attitude/motivation test battery. Technical Report, University of Western Ontairo.

Gardner, R. C., \& Lambert, W. E. (1972). Attitudes and motivation in second language learning. Rowley, Mass.: Newbury House.

Gardner, R. C., \& Smythe, P.C. (1981). On the development of the Attitude/Motivation Test Battery. Canadian Modern Language Review, 37, 510-525.

Gass, S. M., \& Selinker, L. (Eds.). (1992). Language transfer in language learning: Revised edition. Amsterdam: John Benjamins.

Malim, T., \& Birch, A. (1998). Introductory psychology. London: Macmillan Press.

Malim, T., \& Birch, A. (1998). Introductory psychology. London: Macmillan Press. 
Morgan, C. (1993). Attitudes change and foreign language culture learning. Language Teaching, 26, 63-75.

Muchnick, A. G., \& Wolfe, D. E. (1982). Attitudes and motivations of American students of Spanish. The Canadian Modern Language Review, 88, 254-261.

Sawhney, C. (1998). The role of attitudes and motivation in foreign language learning: The case of German in Delhi. In R.K. Agnihotri, A. L. Khanna \& I. Sachdev (Eds.), Social psychological perspectives on second language learning (pp.119-129). New Delhi: Sage.

Skehan, P. (1998). A cognitive approach to language learning. Oxford: Oxford University Press.

Williams, M., \& Burden, R. (1997). Psychology for language teachers. Cambridge: Cambridge University Press. 